\begin{abstract}
\begin{tabular}{llllllll} 
A & B & S & T & R & A & C & T \\
\hline
\end{tabular}
Baseline data from the Canadian National Longitudinal Survey of Children and Youth were used to evaluate the associations between child care arrangement and poor developmental attainment (PDA). A weighted total of 521,800 children aged 2 to 3 years were studied $(\mathrm{N}=2,709)$. PDA was assessed by agestandardized motor and social development score. Children were grouped by the predominant type of arrangement: care by someone in the child's own home, in another home (family child care), at a child care centre, or none (child care exclusive to parents).

Controlling for socioeconomic status, biological factors and maternal immigration, family dysfunction, hostile parenting and low neighbourhood safety were correlated with PDA and positive parent-child interaction decreased the odds of PDA. Whereas centre child care arrangements were beneficial to development overall $(\mathrm{OR}=0.41,99 \% \mathrm{CI}=0.18,0.93)$, an interaction existed between type of child care and maternal depression; among children with depressed mothers, centre child care was associated with increased odds of PDA. Findings suggest that the associations between child care arrangement and child development involve interactions of factors that influence a child's home environment. Future child development studies exploring these interactions are warranted.
\end{abstract}

\begin{tabular}{llllll} 
A & B & R & E & G & É \\
\hline
\end{tabular}

Les données de base recueillies par l'Enquête Longitudinale Nationale sur les Enfants et les Jeunes ont servi à évaluer les liens entre les dispositions pour la garde d'un enfant et son niveau de développement (ND). On a étudié un total de 521800 enfants âgés de 2 à 3 ans $(\mathrm{N}=2$ 709). Le ND a été déterminé selon les résultats obtenus après des tests de développement moteur et social par catégorie d'âge. On a groupé les enfants selon le genre d'arrangement de garde prédominant : par une personne au foyer de l'enfant, dans un autre foyer (garde familiale), dans une garderie, ou aucun (garde exclusive par les parents).

En tenant compte de la situation socioéconomique, des facteurs biologiques et de l'immigration de la mère, on constate que le dysfonctionnement familial, l'hostilité des parents et un voisinage à bas niveau de sécurité sont en corrélation avec un faible ND. Par contre, les interactions positives parent-enfant diminuent les chances de faible ND. Bien que la présence en garderie ait des effets bénéfiques sur le développement de l'enfant en général $(\mathrm{RC}=0,41$, $99 \% \mathrm{IC}=0,18,0,93)$, une interaction existe entre le genre d'arrangement de garde et la dépression chez la mère; pour les enfants ayant une mère dépressive, la présence en garderie augmente les chances de faible ND. Les résultats de l'enquête suggèrent que les liens entre les dispositions de garde et le ND sont aussi déterminés par l'environnement familial. De plus amples études sur le développement de l'enfant sont nécessaires pour explorer ces interactions.

\title{
Child Care Arrangement and Preschool Development
}

\author{
Teresa To, PhD, ${ }^{1,2}$ Suzanne M. Cadarette, MSc, ${ }^{1,3}$ Ying Liu, MSc ${ }^{1,2}$
}

The first few years of life are a critical developmental period, establishing the groundwork for later adult cognitive ${ }^{1}$ and emotional functioning. ${ }^{2,3}$ The preschool years establish biological, behavioural and psychological systems that will guide children throughout life. ${ }^{1,4}$ Controversy exists as to the impact that child care arrangement may pose on a child's development. Studies suggest that high-quality centrebased or family child care participation is more beneficial in children with a high risk of poor developmental attainment (PDA), such as those with low socioeconomic status (SES), 5 and those living in deprived home environments. ${ }^{6,7}$ Although the relationship among children who attend centre child care is clear: same-age children in high-quality care demonstrate better language development, social competency, ability to regulate their own behaviour, and better academic skills at the end of grade one compared to children in lowquality centre care, ${ }^{8}$ the benefit of centre

1. Population Health Sciences, Research Institute, The Hospital for Sick Children, Toronto

2. Department of Public Health Sciences, University of Toronto, Toronto

3. The Canadian Multicentre Osteoporosis Study Toronto Site, Toronto

Work attributed to: Population Health Sciences, Research Institute, The Hospital for Sick Children, Toronto

Correspondence and reprint requests: Dr. Teresa To, Population Health Sciences, Research Institute, The Hospital for Sick Children, 555 University Ave., Toronto, ON, M5G 1X8

Funding for this project was made available through the Research Institute, The Hospital for Sick Children, Toronto, Ontario.

Disclaimer: This analysis is based on Statistics Canada microdata tape National Longitudinal Survey of Children and Youth that contains anonymized data collected in the 1994/95 Special Survey. All computations on these microdata were prepared by Research Institute of the Hospital for Sick Children and the responsibility for the use and interpretation of these data is entirely that of the authors. care and other child care external to parental care, compared to parent exclusive care, is less clear. It is hypothesized that the impact of non-parental care on child development is dependent on the need for additional learning outside of that received through parental care. ${ }^{9}$ Accordingly, highquality child care participation may improve development in children whose home environment may be under-stimulating or stressful.,10,11 This study uses Canadian population-based data to elucidate how child care arrangements affect development in children aged 2 to 3 years, in light of biological risk markers, child characteristics, the home environment and socioeconomic background. In particular, it was hypothesized that child care external to parental care is beneficial to child development only where supportive and stimulating environment is lacking in the child's home.

\section{METHODS}

Baseline data from the Canadian National Longitudinal Survey of Children and Youth (NLSCY), collected in $1994 / 95$, were used in this study. The NLSCY is a prospective longitudinal survey designed to measure child development, health and well-being. A full description of the NLSCY is available elsewhere. ${ }^{12}$ Developmental attainment was measured by the motor and social development (MSD) scale. This scale was developed from commonly used measures of child development ${ }^{13}$ for use in the U.S. National Longitudinal Survey of Youth. The MSD scale assesses motor, social and cognitive development of children aged less than 4 years, ${ }^{14-16}$ and is predictive of behaviour at 9 and 10 years of age. ${ }^{15}$ 
Children are compared based on agestandardized means. ${ }^{17}$ Statistics Canada has derived Canadian age-standardized scores using NLSCY data. A value 1 standard deviation below the mean was used to categorize children with PDA in this study. ${ }^{12}$

Children aged 2 to 3 years with MSD and child care data were eligible for inclusion $(\mathrm{N}=3,255)$. To ensure consistency between measured variables and to permit details of pregnancy, analyses were restricted to households where the biological mother completed responses $(\mathrm{N}=2,930)$. In the NLSCY, child care data were collected for households in which at least one caretaker was employed or in school. Although single mothers represented 13\% of the NLSCY population, only $43 \%$ of single mothers provided information on child care. Preliminary analysis showed that single mothers with child care information were significantly different from those with no child care data, therefore analyses were also restricted to households with two parents $(\mathrm{N}=2,709$, or a weighted total of 521,800 ).

Child care participation was grouped by the predominant type of arrangement as care by someone in the child's own home, in another home (family child care), at a child care centre, or none (child care exclusive to parents). Biological, social and environmental factors were considered in our analyses. Biological and child covariates included pre-maturity $(<37$ weeks gestation); low birthweight (LBW; birthweight $<2500 \mathrm{~g}$ ); and the child's sex, age, and temperament. Child temperament was assessed using a modified ${ }^{12}$ version of the Infant Characteristics Questionnaire (ICQ).$^{18}$ An age-standardized value above $1 \mathrm{SD}$ was used to identify difficult temperament. ${ }^{19}$

Socioeconomic variables included maternal employment (yes/no), low maternal education (less than high school) and low income adequacy. Income adequacy was determined through Statistics Canada's derived variable that accounts for household size and income. A dichotomous grouping for low income adequacy was created to follow Statistics Canada's low income cut-offs for 1995.20

Home environment was characterized by family dysfunction, maternal social support, maternal depression, positive parent-

\begin{tabular}{|c|c|c|}
\hline \multicolumn{3}{|c|}{$\begin{array}{c}\text { TABLE I } \\
\text { Unadjusted Odds Ratio Estimates } \ddagger \text { for } \\
\text { Poor Developmental Attainment, } \dagger \mathrm{N}=\mathbf{5 2 1 , 8 0 0}\end{array}$} \\
\hline Characteristic & OR & $(99 \% \mathrm{CI})$ \\
\hline $\begin{array}{l}\text { Biological and Child Factors } \\
\text { Sex (female reference) } \\
\text { Age ( } 2 \text { years reference) } \\
\text { Premature } \\
\text { Low birthweight } \\
\text { Difficult temperament }\end{array}$ & $\begin{array}{l}2.53 \\
1.42 \\
1.49 \\
2.63 \\
1.74\end{array}$ & $\begin{array}{l}(1.83,3.49)^{* *} \\
(1.05,1.93)^{*} \\
(0.94,2.34) \\
(1.54,4.49)^{* *} \\
(1.18,2.56)^{* *}\end{array}$ \\
\hline $\begin{array}{l}\text { Social and Environmental Factors } \\
\text { Socioeconomic Status } \\
\text { Maternal employment } \\
\text { Low income adequacy } \\
\text { Low maternal education }\end{array}$ & $\begin{array}{l}0.68 \\
1.90 \\
1.54\end{array}$ & $\begin{array}{l}(0.50,0.92)^{*} \\
(1.22,2.95)^{* *} \\
(0.99,2.40)\end{array}$ \\
\hline $\begin{array}{l}\text { Parental Factors and Home Enviro } \\
\text { Maternal immigration } \\
\text { Maternal depression } \\
\text { No maternal social support } \\
\text { Family dysfunction } \\
\text { Hostile parenting } \\
\text { Positive parent-child interaction } \\
\text { Low neighbourhood safety } \\
\text { Single child }\end{array}$ & $\begin{array}{l}1.64 \\
1.90 \\
1.36 \\
1.80 \\
1.48 \\
0.54 \\
1.90 \\
1.03\end{array}$ & $\begin{array}{l}(1.12,2.38)^{* *} \\
(1.38,2.63) \\
(0.54,3.44) \\
(1.10,2.95)^{*} \\
(1.07,2.06)^{*} \\
(0.37,0.79)^{* *} \\
(1.38,2.63) \\
(0.73,1.47)\end{array}$ \\
\hline $\begin{array}{l}\text { Child Care Arrangement } \\
\text { Child care participation } \\
\text { Child care type } \\
\text { Own home } \\
\text { Family care } \\
\text { Centre care } \\
\text { None (exclusive to parents) }\end{array}$ & $\begin{array}{l}1.88 \\
1.85 \\
0.56 \\
1.00\end{array}$ & $\begin{array}{l}(0.53,1.45) \\
(0.59,1.23) \\
(0.31,1.04)\end{array}$ \\
\hline
\end{tabular}

child interaction, and hostile parenting practices. The general functioning subscale of the McMaster Family Assessment Device ${ }^{21,22}$ was used to measure family dysfunction, ${ }^{23}$ the level of maternal social support was assessed using a shortened version of the Social Provisions Scale, ${ }^{24}$ and the frequency of maternal depressive symptoms was assessed using an abbreviated version of the Centre for Epidemiological Studies-Depression (CES-D) Scale. ${ }^{25}$ Coding of variables was consistent with previous dichotomous schemes, i.e., family dysfunction (score $\geq 15$ ), ${ }^{26,27}$ low social support (score $\leq 9),{ }^{27}$ and moderate to severe maternal depression (score $\geq 13$ ). ${ }^{27}$

A Parenting Scale based on Strayhorn and Weidman's Parenting Practices Scale ${ }^{28}$ was developed by Boyle of McMaster University $^{12}$ for use in the NLSCY. Positive parent-child interaction and hostile parenting were assessed in this study. A score in the highest quartile was used to indicate a high degree of positive parent-child interaction and hostile parenting respectively. Other factors relevant to the child's home environment included being a single child, maternal immigration and neighbourhood safety. The neighbourhood score was based on a revised version of the Simcha-Fafan Neighborhood Questionnaire. The lowest quartile of neighbourhood safety was used to identify a low degree of safety.

Demographic and family characteristics of the study population were evaluated by presence and type of child care arrangement. Pearson chi-square and unadjusted logistic regression were used to test the statistical significance of PDA within categories of covariates. Interactions between type of child care arrangement and: LBW, prematurity, low income adequacy, low maternal education, positive parent-child interaction, hostile parenting, family dysfunction, maternal social support, maternal depression, and neighbourhood safety were tested. In addition, the interaction between positive parent-child interaction and child temperament was explored. Backwards selection techniques were used in multiple logistic regression model building. After controlling for child age, sex, SES (low income, low maternal education) and maternal immigration, only statistically 


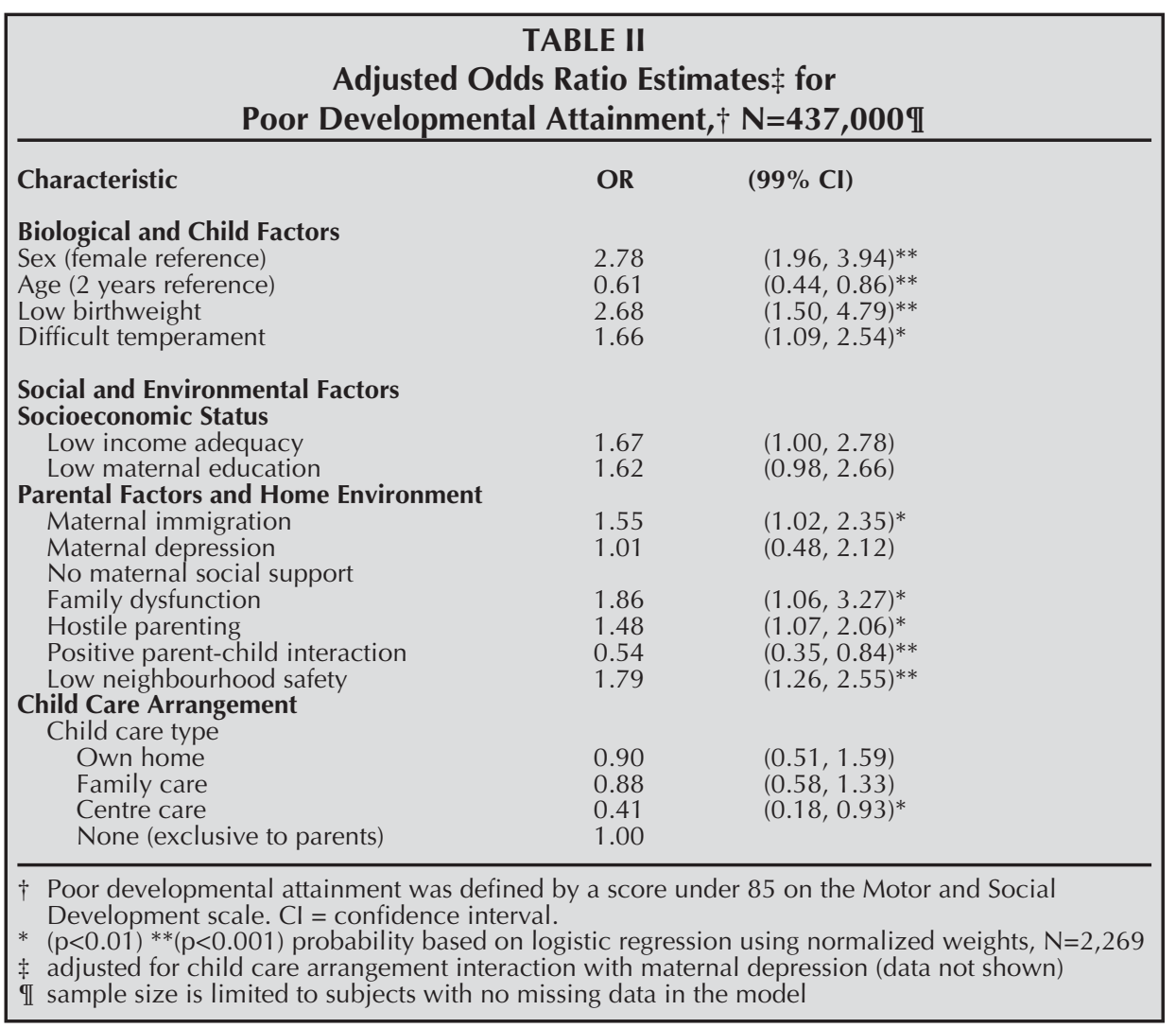

significant variables $(\mathrm{p}<0.01)$ were permitted into the final regression model. Within-interaction comparisons were evaluated in the multiple logistic regression model. ${ }^{29}$

Statistical analyses were weighted up to the population level. Corrections for the effect of sampling design on estimated parameters were produced using coefficients of variation derived by Statistics Canada. ${ }^{14}$ Standardized sample weights (normalized with a mean of one $\mathrm{e}^{30}$ ) were used with a p-value of 0.01 (as opposed to $0.05)$ in logistic regressions to reduce variance estimate bias and partially correct for lack of NLSCY sample design information.

\section{RESULTS}

Forty-five percent of children's primary child care arrangement was external to parental care. Children whose primary child care arrangement was exclusive to parents had significantly higher proportions of low SES (low income adequacy, and low maternal education), hostile parenting, difficult temperament and positive parent-child interactions $(\mathrm{p}<0.05)$. However, twice the number of children in child care did not have siblings $(32.2 \%$ vs. $15.9 \%$ were a single child). Demographic and family characteristics were also explored by predominant type of child care arrangement. Three out of every four children with child care external to parental were cared for by someone in a home other than their own (family child care; $78.1 \%$ ). Low income adequacy and lack of maternal social support were highest, and proportions of maternal employment and positive parent-child interactions were lowest in children receiving centre child care. Maternal immigration and lack of maternal social support were lowest among children in family child care. Further information regarding the study population may be obtained from the primary author.

Table I presents the crude odds ratio (OR) estimates for PDA for each covariate. In addition to biological factors, many social and environmental factors were associated with PDA. Low income adequacy, maternal immigration, family dysfunction and hostile parenting were associated with increased odds of PDA, whereas maternal employment and positive parent-child interaction were associated with decreased odds of PDA. Given that children of work- ing mothers are more likely to receive care external to parents, maternal employment was omitted from adjusted analysis. As well, LBW is a known correlate of prematurity, therefore, only LBW or prematurity was permitted into multiple variable modelling. Results of multiple logistic regression are provided in Table II. Controlling for sex, age, maternal immigration and low SES, factors associated with increased odds of PDA included: LBW, difficult temperament, family dysfunction and low neighbourhood safety; protective factors included high positive parent-child interaction and centre child care arrangement. Overall, children with centre child care had lower odds of PDA (OR=0.41, 99\% CI=0.18, $0.93)$, compared to child care exclusive to parents. A significant interaction was observed between type of child care arrangement and maternal depression. Given the large coefficients of variation in univariate analyses, results of this interaction are presented in text only. All types of child care external to parents improved the odds of normal developmental attainment, provided that the child was not disadvantaged by maternal depression. Among children with a depressed mother, centre child care was associated with increased odds of PDA $(\mathrm{p}<0.01)$.

Limitations of results are inherent in using the NLSCY baseline data. First, data from this study report associations only (cross-sectional), thus neither the direction of association, nor causality may be implied. Second, whereas reported coefficients of variation may be overestimated, ${ }^{12}$ the variance reported in regression analyses may be underestimated due to lack of cluster adjustment. Although two techniques were used to minimize errors by underestimating variances in logistic regressions: the use of normalized (standardized) weights, and a stricter level of statistical significance $(p<0.01)$, we may have overestimated the sample variation. For example, many interactions were statistically significant at a $\mathrm{p}$-value of 0.05 . These included interactions between child care arrangement and: family dysfunction, hostile parenting, LBW and maternal depression, as well as between difficult temperament and positive parent-child interaction. Unfortunately, since we cannot adjust fully 
for sampling design, we cannot be confident in these findings (interactions $\mathrm{p}<0.05)$. Furthermore, given that child care data were restricted to families with at least one caregiver employed or in school, observations were limited to households with two parents. We recognize that associations may be different both in singleparent families, and in unemployed families who are not in school. Further research exploring interactions between type of child care arrangement and developmental outcomes are warranted.

\section{DISCUSSION}

To evaluate how child care arrangements influence child development, analysis of an ecological model which considers the home environment, the child care environment, and the personal characteristics of the child is required. ${ }^{710,31}$ However, evaluation of an ecological model has been neglected in child care research. ${ }^{27}$ Therefore, in addition to biological factors, social factors, environmental factors and other child characteristics were studied. Results suggest that child care arrangement may have positive influences on the cognitive development of children aged 2-3 years. All types of child care were in the direction of benefit over care exclusive to parent(s), however, only centre child care reached statistical significance. Preschoolers need a stable setting with developmentally appropriate materials. The environment must be comforting, enriching and supportive. ${ }^{7,8}$ Environmental experiences which enable young children to interact and problem solve stimulate new developmental skills. ${ }^{8}, 32$ Although centre child care may be reliable, well equipped and subject to regulation, ${ }^{31}$ the individual child may receive inadequate attention because of low staff-child ratios. ${ }^{8,31,33,34}$ In Canada, the quality of child care is extremely variable. ${ }^{35}$ In fact, regulated child care spaces in 1995 existed for only about $8.4 \%$ of children who needed child care; ${ }^{36}$ thus the quality of care is largely unknown. Children in group care who are in need of secure adult attachment because of the lack of such attachment with parents, are unlikely to experience developmental benefits unless there are few children per adult and they have teachers who provide developmentally appropriate interactions with each child. ${ }^{37}$ In this study, the odds of PDA were generally less for children in centre child care compared to those with no child care arrangement $(\mathrm{OR}=0.41 ; 95 \% \mathrm{CI}=0.18,0.93)$. However, a reverse relationship was observed for children whose mother exhibited moderate to severe depression. This suggests i) that centre child care may provide insufficient individual attention required by children whose mother has depression, or ii) that these children attend centre child care programs of lower quality. The observed results are likely a composite of the quality - families who are less stressed and better educated tend to use higher-quality care, while those who are more stressed economically and psychologically tend to use lower-quality $\mathrm{care}^{31}-$ and individual needs for secure attachment among children whose mother experiences moderate to severe depression. This hypothesis is highlighted by the findings that among children with child care external to parental care, children with centre child care had i) higher proportions of low income adequacy and lack of maternal social support, and ii) lower proportions of maternal employment and positive parent-child interactions. As well, Kohen et al.'s analysis revealed that mothers of children who experienced at least one change in care arrangements had poorer mental health ratings than mothers of children who experienced no changes in care. ${ }^{13}$ Unfortunately, the presented hypothesis to the lack of quality centre child care for children exposed to maternal depression could not be evaluated conclusively, as the quality of child care was not assessed in the NLSCY.

The data in this study provide preliminary support to the benefits of child care arrangement, and suggest that the associations between child care arrangement and PDA involve interaction between social factors influencing the child's home environment. Interactions between maternal depression and type of child care arrangement on developmental outcomes appears particularly strong. Further ecological analysis between the interaction of factors affecting child development is warranted.
Evaluation of the interactions between children disadvantaged by low SES and poor home environment with type of child care arrangement should be explored, adding a component to access the quality and continuity of child care received.

\section{ACKNOWLEDGEMENT}

Funding for this project was made available through the Research Institute, The Hospital for Sick Children, Toronto, Ontario, Canada. Preliminary results of this research were presented at the conference meeting of the Canadian Society for Epidemiology and Biostatistics in Vancouver, May 5-8, 1999. The authors acknowledge the contributions of Dr. Astrid Guttmann in providing helpful comments and feedback throughout this research project.

\section{REFERENCES}

1. Ramey CT, Ramey SL. Prevention of intellectual disabilities: Early interventions to improve cognitive development. Prev Med 1998;27:224-32.

2. Berlin LJ, Brooks-Gunn J, McCarton C, McCormick MC. The effectiveness of early intervention: Examining risk factors and pathways to enhanced development. Prev Med 1998;27:23845.

3. Doherty G. The Great Child Care Debate: The Long-term Effects of Non-parental Child Care. Toronto: Childcare Resource and Research Unit, 1996.

4. Bertrand JØ. Enriching the preschool experiences of children. In: Canada Health Action: Building on the Legacy. Volume 1. Determinants of Health: Children and Youth. Quebec: Éditions MultiMondes, 1998;3-46.

5. Caughy MO, DiPietro JA, Strobino DM. Daycare participation as a protective factor in the cognitive development of low-income children. Child Development 1994;65:457-71.

6. Steinhauer PD. Developing resiliency in children from disadvantaged populations. In: Canada Health Action: Building on the Legacy. Volume 1. Determinants of Health: Children and Youth. Quebec: Éditions MultiMondes, 1998;47-102.

7. Dilks SA. Developmental aspects of child care. Pediatric Clinics of North America 1991;38:1529. 43.

8. Doherty G, Stuart B. The association between child care quality, ratio and staff training: A Canada-wide study. Can J Research in Early Childhood Education 1997;6:127-38.

9. Desai S, Chase-Lansdale PL, Michael RT. Mother or market? Effects of maternal employment on the intellectual ability of 4-year-old children. Demography 1989;26:545-61.

10. Caldwell BM. Impact of day care on the child. Pediatrics 1993;91:225-28.

11. Lamb ME. Effects of nonparental child care on child development: An update. Can J Psychiatry 1996;41:330-42.

12. Human Resources Development Canada and Statistics Canada. National Longitudinal Survey 
of Children and Youth. User's Handbook and Microdata Guide. Ottawa: Minister of Industry, 1997.

13. Poe GS. Design and Procedures for the 1981 Child Health Supplement to the National Health Interview Survey. Working paper series. Hyattsville, MD: National Center for Health Statistics, 1986.

14. Baker PC, Kech CK, Mott FL, Quinlan SV. NLSY Child Handbook - Revised Edition. A Guide to the 1986-1990 National Longitudinal Survey of Youth - Child Data. Columbus, Ohio: Center for Human Resource Research, The Ohio State University, 1993.

15. Mott FL, Baker PC, Ball DE, et al. The NLSY Children 1992: Description and Evaluation Revised. Columbus, Ohio: Center for Human Resource Research, The Ohio State University, 1998.

16. Center for Human Resource Research. NLSY79 1996, Child and Young Adult Data Users Guide. Columbus, Ohio: Center for Human Resource Research, The Ohio State University, 1998.

17. Peterson JL, Moore KA. Motor and Social Development in Infancy: Some Results from a National Survey. Washington: Child Trends, 1987.

18. Bates JE, Freeland CAB, Lounsbury ML. Measurement of infant difficultness. Child Development 1984;50:794-803.

19. Kohen DE, Hertzman C, Wiens M. Environmental Changes and Children's Competencies. Hull, Quebec: Applied Research Branch, Strategic Policy, Human Resources Development Canada, 1998;54.

20. Statistics Canada. Low Income Cut-Offs. Ottawa, 1996

21. Epstein NB, Bishop DS, Levin S. The McMaster Family Assessment Device. J Marital and Family Therapy 1978;9:19-31.

22. Epstein NB, Baldwin LM, Bishop DS. The McMaster Family Assessment Device. J Marital and Family Therapy 1983;9:171-80.

23. Byles J, Byrne C, Boyle MH, Offord DR. Ontario Child Health Study: Reliability and Validity of the General Functioning Subscale of the McMaster Family Assessment Device. Family Process 1988;27:97-104

24. Cutrona CE, Russell DW. The provision of social relationships and adaptation to stress. Advances in Personal Relationships 1989;1:37-67.

25. Radloff LS. The CES-D scale: A self-report depression scale for research in the general population. Applied Psychological Measurement 1977;1:385-404.

26. Ross DP, Scott K, Kelly MA. Overview: Children in Canada in the 1990s. Growing up in Canada: National Longitudinal Survey of Children and Youth. Ottawa: Statistics Canada and Human Resources Development Canada, 1996;15-45.

27. Landy S, Tam KK. Understanding the Contribution of Multiple Risk Factors on Child Development at Various Ages. Hull, Quebec: Applied Research Branch, Strategic Policy, Human Resources Development Canada, 1998;30.

28. Strayhorn JM, Weidman CS. A parent practices scale and its relation to parent and child mental health. J Am Acad Child Adolesc Psychiatry 1988;27:613-18.

29. Schlesselman JJ, Stolley PD. Multivariate analysis. In: Case-control Studies: Design, Conduct, Analysis. New York: Oxford University Press, 1982;227-90.

30. Millar WJ, Hill GB. Childhood asthma. Health Reports 1998;10:9-21

31. American Psychiatric Association task force on day care for pre-school children. Day care for early preschool children: Implications for the child and family. Am $J$ Psychiatry 1993;150:1281-87.

32. Majnemer A. Benefits of early intervention for children with developmental disabilities. Seminars in Pediatric Neurology 1998;5:62-69.

33. Iannantuono A, Eyles J. Meanings in policy: A textual analysis of Canada's "Achieving Health for All” document. Soc Sci Med 1997;44:1611-21.

34. NICHD Early Child Care Research Network. Child Outcomes When Child Care Center Classes Meet Recommended Standards for Quality. Am J Public Health 1999;89:1072-77.

35. National Council of Welfare. Preschool
Children: Promises to Keep. Ottawa: Minister of Public Works and Government Services Canada, 1999.

36. Childcare Resource and Research Unit. Child Care in Canada: Provinces and Territories 1995. Toronto: Childcare Resource and Research Unit, 1997.

37. Burchinal MR, Roberts JE, Nabors LA, Bryant DM. Quality of center child care and infant cognitive and language development. Child Development 1996;67:606-20

Received: August 11, 1999

Accepted: June 5, 2000

\section{FATAL CONSUMPTION}

\section{Rethinking Sustainable Development Robert Woollard \& Aleck Ostry, eds.}

\section{"Why do we claim to value sustainability yet act in an unsustain able fashion?"}

Woollard and Ostry look at this and other important questions in their discussion on the destructive nature of consumption-based societies. The text provides a link between the broad conceptualization of issues and the practical reality of human activity.

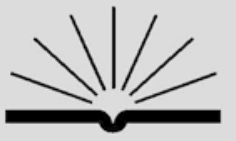

UBCPress
For this and other UBC Press Publications, order from Raincoast Books:

Tel: 1-800-561-8583 / Fax: 1-800-565-3770 Email: custserv@aincoast.com

WWW.UBCPRESS.UBC.CA 